\title{
INVESTMENT LITERACY, RISK TOLERANCE AND MUTUAL FUND INVESTMENTS: AN EXPLORATORY STUDY OF WORKING ADULTS IN KUALA LUMPUR
}

\author{
Nurul Shahnaz Mahdzan* \\ University of Malaya \\ Rozaimah Zainudin \\ University of Malaya \\ Siew-Chan Yoong \\ University of Malaya
}

\begin{abstract}
Financial literacy empowers consumers to make more informed financial decisions, including investing in mutual funds. In this study, the sociodemographic profile of working adults with low investment literacy visà-vis high investment literacy are examined first. Next, the impact of investment literacy and risk tolerance on the likelihood of investing in mutual funds are explored. Among a sample of 260 working adults comprising mainly of Masters of Business Administration (MBA) students from a leading public higher institution in Kuala Lumpur, Malaysia, the study shows that those with Business/Economics education backgrounds have the highest investment literacy and are more likely to invest in mutual funds compared to individuals from the Arts and other miscellaneous backgrounds. Although Muslims are the least literate in investment matters, they are more likely to hold mutual fund investments relative to those who profess Christianity and Hinduism. Individuals with relatively high income and occupational levels have relatively higher investment literacy. Risk tolerance does not influence the likelihood of investing in mutual fund investments. Policymakers should focus on females, those with Arts education background, Muslims, and those from the lower income/employment ranks to increase their investment literacy through financial education workshops. Mutual fund companies may consider embarking an aggressive knowledge sharing videos related to mutual funds via non-mainstream media such as social media to increase the penetration of mutual fund investments, among the untapped markets.
\end{abstract}

Keywords: Investment literacy; Mutual fund investment; Unit trust; Risk tolerance; Stock market

Received: 11 July 2018

Accepted: 30 December 2019

\section{INTRODUCTION}

The emergence of new and more sophisticated financial products in the marketplace along with the expansion of delivery channels have resulted in an increased number of individuals who actively participate in financial markets. The types of financial assets range from low risk fixed

\footnotetext{
* Corresponding author: Faculty of Business and Accountancy, University of Malaya, 50603 Kuala Lumpur. Tel: +60379673958. Email: n_shahnaz@um.edu.my
} 
income instruments to high risk equity investments, all of which require investors to have some basic financial knowledge in order to make informed decisions in the selection of these products. The investment options that are available in the market allow investors to tailor their selection to meet their personal financial goals. Investors who choose to invest in risky investments are able to accumulate higher wealth and net worth in the long run (Gittleman \& Wolff, 2004). On the other hand, it may be argued that those who do not invest in equities may experience welfare loss due to the lack of exposure to equity premiums (Cocco, Gomes \& Maenhout, 2005). Heo, Grable and O'Neill (2017) argue that individuals who have long term financial goals may be at risk if wealth is kept in assets with low rates of return, due to the exposure to inflation and longevity risk (Goldsmith, 2009) that could erode the future value of assets. Therefore, investments in equity, including mutual funds, are essential in the achievement of financial stability and well-being (Heo et al., 2017).

Apart from direct stock investments, mutual funds are regarded as a more acceptable mode of investment by risk averse individuals. Mutual funds, which are also commonly known as unit trusts in Malaysia, pool money from a large number of investors and are professionally managed by fund managers. It has become an increasingly popular investment tool among Malaysians as it opens up private investors' access into capital markets despite lacking sizeable monetary funds and expertise in regards to the workings of the stock market. The advantage of investing in mutual funds as opposed to direct stock investment is that investors are able to select funds that best suit their personal risk profile and financial goals. Also, by pooling funds with others, investors are able to diversify their portfolios in order to minimise financial risk at a relatively low cost (Ripain \& Ahmad, 2018).

Traditional finance theories such as the modern portfolio theory argue that risk averse investors will hold a certain level of risky assets as long as the expected returns commensurate the undertaken risk (Markowitz, 1952; Eeckhoudt, Gollier \& Schlesinger, 2005). Theories of choice under uncertainty argue that rational investors will select a combination of assets that maximises his or her expected utility. In selecting among risky assets, investors will consider the trade-off between the expected return and riskiness of assets to determine the best combination of assets in a portfolio (Markowitz, 1952). Mutual funds provide convenience to investors as they are managed by professional fund managers (Ripain \& Ahmad, 2018). Hence, investors do not have to be actively involved in rebalancing the risky and non-risky asset proportions in their portfolios.

More recently, studies have explored the importance of financial knowledge and financial/investment literacy in influencing individuals' investment choices. Lack of financial literacy is a common issue among many investors globally (Lusardi \& Mitchell, 2011a). Many scholars and policy makers have thus increased their attention to examine the importance of financial and investment literacy in financial decision making, including stock participation (Van Rooij, Lusardi, \& Alessie, 2011), mutual fund investment (Müller \& Weber, 2010), retirement planning (Fornero \& Monticone, 2011), credit card usage (Norvilitis, Merwin, Osberg, Roehling, Young \& Kamas, 2006), and mortgage financing (Gerardi, Goette \& Meier, 2010). However, the evidence regarding the importance of financial literacy in these financial decisions are mixed. Some studies found a significant positive relationship between financial literacy and financial 
decisions, while others found a weak relationship between the two ${ }^{1}$. In addition, the measurements of financial literacy that have been used in the literature varies. Although most studies use quizlike questions to test financial knowledge, the number and type of questions used vary. Some use basic literacy questions testing the respondents about inflation and compound interest (e.g. Lusardi \& Mitchell, 2007a, 2007b, 2011a; Hastings \& Mitchell, 2011) while others use basic plus more advanced questions that focus on stock and bond investments (e.g. Van Rooij et al., 2011; Hassan Al-Tamimi \& Anood Bin Kalli, 2009). However, the most popular measurement is that by Lusardi and Mitchell (2007a, 2007b, 2011b).

The empirical evidence highlights the significant influence of financial literacy on investment, savings, and debt management behaviour. Intense discussions have continued after the Global Financial Crisis on how investors who lacked financial literacy were more vulnerable during the crisis (Guiso \& Viviano, 2014). Hence, accessing financial literacy is critical and still relevant since more sophisticated financial products are continuously being introduced by financial institutions. Therefore, improving financial literacy and knowledge among consumers and participants of financial markets is crucial in overcoming the barriers that may exist between customers and financial institutions.

Developments in the local financial market underscores the importance of understanding how knowledgeable individual investors are in regards to financial matters, as this will have significant implications on their investment decisions. Motivated by the aforesaid factors, this study is an exploratory study focusing on the investment literacy and mutual fund investments among Malaysians. To this end, the objectives of the study are two-fold. First, the demographic profile of individuals with low investment literacy vis-à-vis high investment literacy are examined. Second, the determinants of mutual fund investment, particularly the effects of investment literacy and risk tolerance of investors, are investigated. The analysis is conducted to gauge the differences in investment literacy levels across age groups, religion, gender, income level, and education background, and also to identify who among them are inexperienced and naïve investors. The sample of this study are working adults in Kuala Lumpur, comprising mainly of MBA students of a leading public university in Kuala Lumpur, who are believed to be exposed to various financial products in the market, including mutual funds. The findings are expected to assist authorities such as the Securities Commission Malaysia in providing more focused financial education efforts that target specific groups of potential investors that are likely to have lower investment literacy levels rather than targeting a general, unspecified group.

The remainder of the paper is organised as follows. The next section explains the literature review and hypotheses development. Section 3 presents the data and methodology used in this analysis. Section 4 discusses the findings of the estimated model and finally, Section 5 contains concluding remarks.

\footnotetext{
${ }^{1}$ For example, Van Rooij et al. (2011) found significant evidence of a positive relationship between investment literacy and investment in equities, and Fornero and Monticone (2011) found a significant relationship between financial literacy and pension plan participation. Examples of studies who found a weak relationship between financial/investment literacy and financial decisions are Müller and Weber (2010) in the context of mutual fund investments and Hastings and Mitchell (2018) in the context of retirement wealth and investment behaviours.
} 


\section{LITERATURE REVIEW}

\subsection{Mutual Fund Investments}

Apart from stock market participation, investments in mutual funds have significantly positive impacts on the economic activities of a country (Thomas \& Spataro, 2015) because these funds are channelled to capital markets to fund firms' investments, ultimately leading to economic growth of the nation. However, the phenomenon of low individual participation in stocks and mutual funds continues to persist in both developing and developed countries (Giannetti \& Koskinen, 2010) despite the advantages of minimisation of risks through the dollar-cost averaging technique. Participation in shares and mutual funds still remains at a low level despite their advantages and the reasons for the low participation remains a puzzle (Van Rooij et al., 2011).

Nonetheless, in Malaysia, the mutual fund industry has grown tremendously over the past two decades. Reports from the Securities Commission Malaysia show that the industry experienced a seven-fold growth in total net asset value (NAV) from RM60 billion in 1996 to RM426.98 billion in 2017 (Securities Commission, 2017; The Star, 2013). The mutual fund penetration rate has also grown tremendously over the past decade, from $15.19 \%$ in 2007 to $22.39 \%$ in 2017 (Securities Commission, 2017). While the progression in the mutual fund industry signifies its importance in the Malaysian capital markets and the overall economy, the penetration rate of slightly over $20 \%$ indicates potential room for growth. According to the Capital Market Masterplan 2, the penetration rate for mutual funds is expected to reach up to $34 \%$ by 2020 (Securities Commission, 2011).

Generally, investors' decisions are influenced by financial risk tolerance (Deb \& Singh, 2016) and risk and return factors (see, Arathy, Nair, Sai \& Pravitha, 2015). Apart from the risk-return factor, there could be other factors influencing a mutual fund investor's decisions such as product awareness, perception and social/demographic characteristics (Kaur \& Kaushik, 2016). Additionally, accessibility and benefits of mutual funds have been found to be important determinants in influencing South Africans investors (Rootman \& Kruger, 2016). Within the Malaysian context, Jamaludin and Gerrans (2015) found that perceived plan design, risk tolerance and perceived importance of financial advisors are the factors that influence the likelihood of Malaysian investors investing in retirement saving mutual funds. As for Islamic mutual funds, Yusuff and Mansor (2016) proposed that religiosity, Islamic financial literacy and product knowledge may influence the choice to invest in Islamic mutual funds.

Although the literature reveals many possible factors that may influence mutual fund investments, this study focuses on two behavioural factors that appear to be emphasised in the literature, i.e. investment literacy and risk tolerance. This is because the relationship between investment literacy and mutual fund investments has not been empirically explored in the Malaysian context. Hence, this exploratory study aims to uncover this issue. In addition, risk tolerance is one of the main factors influencing investment decisions as suggested by traditional finance theory, thus it would be interesting to investigate the effect of this variable on investments in managed funds. 


\subsection{Investment Literacy and Investment Decisions}

Interest in consumer financial literacy has increased in recent years from the perspectives of governments, scholars and industry players. Its conceptual and operational definitions, however, have been inconsistent and varied. Remund (2010, p.279) extensively reviewed over one hundred published articles and grouped the conceptual definitions into five categories, which encompass “(i) knowledge of financial concepts, (ii) ability to communicate about financial concepts, (iii) aptitude in managing personal finances, (iv) skill in making appropriate financial decisions and (v) confidence in planning effectively for future financial needs". In differentiating financial knowledge and financial literacy, Huston (2010) describes the former as a "stock of knowledge acquired through education and/or experience specifically related to essential personal finance concepts and products" while the latter is argued to have an additional dimension that focuses on the individuals' ability to appropriately apply the financial knowledge in financial decision-making processes. Similarly, the OECD International Network on Financial Education (INFE) defined financial literacy as "a combination of awareness, knowledge, skill, attitude and behaviour necessary to make sound financial decisions and ultimately achieve individual financial wellbeing" (Atkinson \& Messy, 2012).

A number of studies have attempted to indentify the reasons for low participation in stock markets as well as in mutual funds by individual investors (e.g. Sivaramakrishnan, Srivastava \& Rastogi, 2017; Xia, Wang \& Li, 2014; Almenberg \& Dreber, 2015; Alexander, Jones \& Nigro, 1998; Müller \& Weber, 2010; Jonsson, Söderberg \& Wilhelmsson, 2017). The empirical evidence tends to support the significant effects of investment literacy on individial investors enganging into these stocks or mutual funds. However, Müller and Weber (2010) contended this view, where their results suggest that investment illiteracy among mutual funds customers could not totally explain the growth rate of active managed funds. Their result is isolated where their analysis was more focused on active mutual funds rather that other types of mutual funds that are less technical and more acceptable to the public.

In addition, studies show that individuals who have higher investment literacy are more likely to participate efficiently in risky asset markets (Lusardi \& Mitchell, 2005). People who are illiterate in investment matters and fail to understand the operations of the stock market and asset pricing are less likely to invest in the stock market (Van Rooij et al., 2011). However, investors with higher investment literacy who are equipped with more financial knowledge are more cautious in investing directly in stocks, and prefer investing in managed funds such as mutual funds (Chu, Wang, Xiao \& Zhang, 2017). They highlight that individuals with lower investment literacy are prone to make poor financial decisions related to investments, savings and borrowing, resulting in adverse effects on their wealth accumulation. Generally, studies have found that individuals with lower financial literacy are prone to making sub-optimal financial decisions, for example, they are less likely to plan for retirement (Lusardi \& Mitchell 2007a), incur high borrowing costs (Lusardi $\&$ Scheresberg, 2013) and save less (Lusardi \& Mitchell, 2007b).

A number of studies on financial and investment literacy have also been conducted in the context of Malaysia. Among the pioneering studies in Malaysia was one conducted by Sabri, MacDonald, Hira and Masud (2010) who found that the financial literacy scores among 2,519 university students in Malaysia were below average where these young respondents scored less than half of the questions on financial knowledge correctly. Two studies conducted in the Klang Valley that 
employed Lusardi's (2007b) measurement of investment literacy found that most respondents scored high in basic financial literacy questions but scored relatively low in investment literacy (e.g. Boon, Yee \& Ting, 2011; Mahdzan \& Tabiani, 2013). Idris, Krishnan and Azmi (2013), who examined the financial literacy of 430 Malaysian civil servant youths, discovered that more than $90 \%$ of the respondents achieved high and moderate levels of financial literacy. More recently, Ali, Abd Rahman and Bakar (2015) found that the financial literacy among a large sample of 1,957 Malaysian investors was rather high, at $66.67 \%$. Overall, these results suggest that Malaysians seem to score fairly well in basic literacy questions, but not as well in the investment literacy items which are more advanced. Furthermore, the financial literacy scores seem to significantly differ among undergraduate students and more sophisticated adults such as investors.

Building upon the past findings of the literature, this study posits that higher levels of investment literacy will increase the likelihood of participating in mutual fund investments. Thus, the following hypothesis is tested:

$\boldsymbol{H}_{1}:$ There is a positive relationship between investment literacy and the likelihood of investing in mutual funds.

\section{3. $\quad$ Risk Tolerance and Investment Decisions}

Another factor influencing participation in shares or mutual funds is risk tolerance. Risk tolerance is measured by the maximum amount of volatility that individual investors are willing to accept when making investment decisions (Grable \& Lytton, 1999). Markowitz's Portfolio Theory (1952) explains that individuals who are risk adverse may not participate in the share market despite being able to gain higher returns on their investments. Investors' risk tolerance levels are dependent on their attitudes to risk which would eventually affect their investment behaviour (Jagongo \& Mutswenje, 2014; Jacobs-Lawson \& Hershey, 2005; Mahmood, Ahmad, Khan \& Anjum, 2011; Jamaludin \& Gerrans, 2015). Generally, previous studies confirm a significant positive relationship between individual financial risk tolerance and his/her investment decisions. In regards to other types of investments, financial risk tolerance has also been found to significantly influence Malaysian investors' decisions to invest in gold (Fauzi, Husniyah, Fazli, \& Amim, 2017). However, individuals' level of risk acceptance varies among investors and are affected by various factors such as the level of wealth (Cohn, Lewellen, Lease \& Schlarbaum, 1975), age, income and education (Riley \& Chow, 1992), as well as gender (Almenberg \& Dreber, 2015). Hence, individuals would only invest their funds if they perceive that the risk of the investment is acceptable to their level of risk tolerance. Similar to Mahmood et al. (2011), the researchers agree that risk attitudes play an important role in the investment decision process and posit that individual risk tolerance has a significant impact on individual's participation in mutual funds.

$\boldsymbol{H}_{2}:$ There is a positive relationship between risk tolerance and the likelihood of investing in mutual funds.

\subsection{Sociodemographic Variables}

For the first research objective, the sociodemographic profile of individuals with low investment literacy vis-à-vis high investment literacy are examined. This investigation is in line with previous studies that have found significant differences in investment literacy across socioeconomic and 
demographic groups. Generally, women tend to have lower investment literacy than men (Lusardi \& Mitchell, 2007b; Lusardi \& Mitchell, 2008: Hassan Al-Tamimi \& Anood Bin Kalli, 2009; Lusardi \& Mitchell, 2011a) and are less likely to participate in the stock market (Van Rooij et al. 2011; Jamaludin \& Gerrans, 2015). Wang (2011) found that younger women need to increase their financial knowledge and experiences to enhance their wealth management. Insignificant results are found in Fonseca, Mullen, Zamarro and Zissimopoulos (2012), where their results conclude no significant difference in the level of financial literacy between men and women.

In regards to age, Lusardi, and Mitchell (2011a) found that the older generation (baby boomers) have lower financial knowledge compared to the younger generation. A lower participation among younger investors may be due to having inadequate surplus funds to invest in stocks or mutual funds (Constantinides, Donaldson \& Mehra, 2002). Yoo (1994) highlighted that the older generation prefer to avoid investing in stocks compared to the younger generation. He argues that the younger generation increase "their holdings of equities while working and decrease their risk exposure once they retire”. In contrast, Davar and Gill (2007) found that older investors tend to highly participate in equities since they have ample of surplus funds, developed maturity and experience in making investment decisions.

Besides age and gender, empirical evidence suggest that income and education are important in determining the level of financial literacy among individuals (Fonseca et al., 2012; Hassan AlTamimi \& Anood Bin Kalli, 2009). Investors with higher income are likely to be more educated, hence they tend to have better understanding on financial-related matters and are considerably wealthier to be able to participate in sophisticated financial investments. However, Jamaludin and Gerrans (2015) found an insignificant relationship between age, education background and income level towards the likelihood of investment choices in Malaysia. Hassan Al-Tamimi and Anood Bin Kalli (2009) suggested that religious reasons were the most influential factor that affects the investment decisions of the United Arab Emirates investors. Other scholars have also argued that religion shapes the moral and ethical values of an individual, which would then influence his or her identity and behaviour, including making financial decisions and risk-taking attitudes (Barro \& McCleary, 2003; Benjamin, Choi \& Fisher, 2016; Hess, 2012; Léon \& Pfeifer, 2013). There is also evidence indicating that compared to other religions, Muslims are less inclined towards investing in risky assets (Léon \& Pfeifer, 2013), plausibly due to their religious teachings that forbid investments of excessive risk and uncertainty. Nonetheless, other studies have found that religious beliefs were not among the significant determinants influencing individual's investment decisions (Brimble, Vyvyan \& Ng 2013; Jamaludin \& Gerrans, 2015).

Based on the above contradictions in findings, this study includes demographic variables as the control variables in the main model of analysis.

\subsection{Research Gaps}

This paper contributes to the literature by exploring the impact of investment literacy on investments in managed funds in the context of an emerging market in Asia. Although there have been prior studies that have examined the impact of investment literacy in direct stock market participation (e.g. Van Rooij et al., 2011) and mutual funds (e.g. Müller \& Weber, 2010; Pellinen, Törmäkangas, Uusitalo \& Raijas, 2011), these studies have been mainly conducted in developed Western countries with relatively larger industry sizes and populations that are relatively wealthier 
and educated (see, Khorana, Servaes \& Tufano, 2005). In addition, although there are studies in the Malaysian context that have focused on financial and investment literacy (e.g. Boon et al., 2011; Mahdzan \& Tabiani, 2013; Idris, et al., 2013) and also mutual fund investments (e.g. Jamaludin et al., 2012; Jaiyobea, Adewale, Haron \& Che Ismail, 2018), it is to the best of the researchers' knowledge that none have examined the relationship between investment literacy and mutual investments in the Malaysian context. In an emerging country such as Malaysia, the mutual fund penetration rate is relatively smaller and less matured than the developed Western markets. These differences suggest possible different outcomes in regards to the relationship between investment literacy and in mutual fund investments, which may provide some basis of comparison with other studies conducted in other international contexts.

\section{METHODOLOGY}

\subsection{Data and Sample}

According to the Department of Statistics Malaysia (n.d.), there are approximately 870,000 employed individuals in Kuala Lumpur. To capture responses from working adults in this area, this study employed a quantitative approach to achieve the research objectives as discussed in Section 1. Data was collected via a self-administered questionnaire (both in hardcopy and electronic form) that was distributed via a non-probability, convenience sampling approach to the Master of Business Administration (MBA) students of a leading public higher education institution in Kuala Lumpur, Malaysia. In addition, a snowballing technique was also employed to encourage a larger number of participants. Although the convenience and snowballing sampling approach have often been criticised for their limitations of lack of generalisability, these methods are chosen due to its time and cost advantage features. The rationale for selecting MBA students as the main sample of the study is to obtain a fairly diverse group of respondents in terms of socio-demographic characteristics. However, it may be possible that due to the snowballing approach, other respondents other than the MBA students may have participated in the study. In this particular university, most of the MBA students are part time students attending evening classes and are employed in various companies and sectors in Kuala Lumpur. The socio-demography of MBA students in this university are also very diverse in terms of age, religion, fields of educational background, income levels and employment ranks. Most importantly, since these postgraduate students are based in the capital city of Malaysia, they are very likely to be exposed to various savings and investment products including mutual funds, hence would be able to provide valuable data to address the research objectives. From the literature, other researchers have also employed the MBA student sample due to the advantages of capturing diversity in the sample, for example, Chatman and Barsade (1995), Friedman, Chi and Liu (2006) and Ferguson and Peterson (2015) in the fields of psychology and social science. According to Bello, Leung, Radebaugh, Tung and Wittleloostuijn (2009), the usage of part time MBA students as a sample should not pose a significant threat to external validity since they represent the working class.

Prior to the actual data collection, a pilot test on 20 respondents was first conducted to ensure that the items were comprehensible and well understood by respondents. Minor revisions were made on the wordings of several items before the actual distribution of the questionnaires. The hardcopy questionnaires were distributed to the MBA students before the start of their evening class and were collected at the end of the class. In addition, the electronic version of the questionnaire was 
also distributed by sharing the link with the respondents. The data collection process took place over a period of approximately one month to attain a large enough sample for the conduct of the study. From a total of 300 printed questionnaires distributed, 198 valid responses were obtained. In addition, 62 responses were obtained via the electronic version. Since this is an exploratory study, the number of observations that were attained (260) were deemed sufficient to allow reliable statistical analyses and inferences to be made regarding the issues that are being investigated.

\subsection{Instrument}

The instrument used in this study was a self-administered questionnaire containing three main sections. Section One contained ten (10) questions pertaining to the demographic profile and background of the respondents. Section Two contained sixteen (16) questions adopted from Van Rooij et al. (2011) to test the investment literacy level of the respondents. This comprehensive measurement of financial literacy includes basic financial literacy and investment literacy questions and has been included in numerous national surveys in the US and have been tested and validated in numerous studies across different age groups, time periods and using different data collection methods (Lusardi \& Mitchell, 2011a). These questions have also been employed in the Malaysian context (e.g. Tan Hoe \& Hung, 2011; Mahdzan \& Tabiani, 2013; Ali, Abd Rahman \& Bakar, 2015) and findings of these studies have appeared to produce consistent outcomes. This suggests that the measurement of investment literacy is deemed reliable and valid since it has not only been tested internationally, but also in the local Malaysian context. Among the questions asked were regarding the respondent's knowledge on interest rates, inflation, stock market and mutual fund investments, and investment risk. To measure the respondents' investment literacy level, correct answers were given a score of 1 , and 0 if otherwise. The total score for the 16 questions were tabulated and the percentage of correct answers were computed. Therefore, the investment literacy measure is a continuous measure, falling between 0 (no correct answers) to 1 (all correct answers).

Section Three included questions to gauge the risk tolerance level of the respondent, worded as follows: "Which of the following statements on this page comes closest to the amount of financial risk that you are willing to take when you save or make an investment?" The question is adopted from a national survey conducted by the Federal Reserve Board in the US called the Survey of Customer Finances (SCF). This question is one of the most common and widely used measurement of risk tolerance in literature (Gilliam, Chatterjee \& Grable, 2010).

To measure the dependent variable of the study, that is, investments in mutual funds, respondents were asked to indicate the types of financial assets and investments they held in their financial portfolio, including mutual funds. From this question, a dummy variable was created whereby respondents who held mutual fund investments were coded as 1, and those who did not have any mutual fund investments were coded as 0 . This simple question is viewed appropriate to determine whether an individual participates in mutual fund investments, which do not require the exact amounts being invested. Simple questions such as this are more advantageous than more complex questions that require computations of the market value of current mutual fund investments which could result in spurious analyses and results (Athey \& Kennickell, 2005). 


\section{RESULTS}

\subsection{Descriptive Analyses}

Frequency analyses were run to have a clearer picture on the demographic profiles and backgrounds of the respondents. Based on Bursa Malaysia (The Star, 2017), 36\% of the total Malaysian Central Depository System (CDS) account holders are aged 25 and below. Due to the sizeable percentage of the CDS account holders among younger investors, this study used the 20 and above age group range for the respondents. Additionally, these respondents are more likely to fall within the age range of working adults and earn stable salaries that may have allocations for mutual fund investments. As can be noted from the results in Table 1, the majority of the respondents fell within the age bracket of 26-35 years (45.5\%). Slightly more than half of the total sample were female $(53.8 \%)$ and the remaining were male $(46.2 \%)$. In regards to religious faith, $43.8 \%$ were Muslims, followed by Buddhists (31.9\%), Christians (13.5\%), Hindu (7.3\%) and other religions $(3.5 \%)$. The proportional order of the religious groups is somewhat in accordance to the proportion of ethnicities of the Malaysian population, whereby the largest ethnic group are the Malays who profess Islam. The Chinese ethnic group is also the second largest ethnic group in Malaysia who usually profess Buddhism.

Table 1: Descriptive Statistics of Respondents' Sociodemographic Profile

\begin{tabular}{|c|c|c|c|}
\hline Variable & & $\begin{array}{c}\text { Frequency } \\
(n=260)\end{array}$ & $\begin{array}{c}\text { Percent } \\
(\%)\end{array}$ \\
\hline \multirow{4}{*}{ Age } & $20-25$ & 95 & 36.5 \\
\hline & $26-35$ & 118 & 45.4 \\
\hline & $36-45$ & 37 & 14.2 \\
\hline & 46 and above & 10 & 3.8 \\
\hline \multirow{2}{*}{ Gender } & Female & 140 & 53.8 \\
\hline & Male & 120 & 46.2 \\
\hline \multirow{5}{*}{ Religion } & Muslim & 114 & 43.8 \\
\hline & Buddhist & 83 & 31.9 \\
\hline & Christian & 35 & 13.5 \\
\hline & Hindu & 19 & 7.3 \\
\hline & Others & 9 & 3.5 \\
\hline \multirow{5}{*}{ Occupation level } & Junior Executive & 121 & 46.5 \\
\hline & Executive & 73 & 28.1 \\
\hline & Management & 43 & 16.5 \\
\hline & Senior Management & 14 & 5.4 \\
\hline & Others & 9 & 3.5 \\
\hline \multirow{6}{*}{ Income level } & Less than RM2,500 & 122 & 46.9 \\
\hline & RM2,501 - RM5,000 & 69 & 26.5 \\
\hline & RM5,001 - RM7,500 & 38 & 14.6 \\
\hline & RM7,501 - RM10,000 & 15 & 5.8 \\
\hline & RM10,001 \& above & 16 & 6.2 \\
\hline & High school College / Diploma /Others & 52 & 20 \\
\hline Education level & Degree & 141 & 54.2 \\
\hline
\end{tabular}




\begin{tabular}{|c|c|c|c|}
\hline Variable & & $\begin{array}{c}\text { Frequency } \\
(\mathrm{n}=\mathbf{2 6 0})\end{array}$ & $\begin{array}{c}\text { Percent } \\
(\%)\end{array}$ \\
\hline & Postgraduate & 67 & 25.8 \\
\hline \multirow{5}{*}{$\begin{array}{l}\text { Education } \\
\text { background }\end{array}$} & Arts & 29 & 11.2 \\
\hline & Business or Economics & 124 & 47.7 \\
\hline & Engineering & 20 & 7.7 \\
\hline & Science & 33 & 12.7 \\
\hline & Others & 54 & 20.8 \\
\hline \multirow{2}{*}{$\begin{array}{l}\text { Investments in } \\
\text { mutual funds }\end{array}$} & No mutual fund investments & 168 & 64.6 \\
\hline & Have mutual fund investments & 92 & 35.4 \\
\hline \multirow{5}{*}{ Risk tolerance } & Not willing to take any financial risks & 67 & 25.8 \\
\hline & $\begin{array}{l}\text { Take average financial risk expecting to earn average } \\
\text { returns }\end{array}$ & 96 & 36.9 \\
\hline & $\begin{array}{l}\text { Take above average financial risk expecting to earn } \\
\text { above average returns }\end{array}$ & 53 & 20.4 \\
\hline & $\begin{array}{l}\text { Take substantial risk expecting to earn substantial } \\
\text { returns }\end{array}$ & 44 & 16.9 \\
\hline & Total & 260 & 100 \\
\hline
\end{tabular}

In terms of occupation, most of the respondents were from the Junior Executive level (46.5\%), followed by Executives (28.1\%), Management (16.5\%), Senior Management (5.4\%) and others (3.5\%). Most respondents fell within the first monthly income range which is less than RM3,000, which is reflective of the occupational level of Junior Executives that have five years of experience or less. More than half of the sample are degree holders, $26 \%$ are postgraduate degree holders, and the remaining $20 \%$ are among the 'other' category (high school/college/diploma/others). Majority of the respondents had either Business or Economics backgrounds (47.7\%), followed by other disciplines (20.8\%), Science (12.1\%), Arts (11.2\%), and lastly, Engineering (7.7\%).

For the item that asked whether the respondent held any mutual fund investments, only $35.4 \%$ of respondents answered positively, while the majority $(64.6 \%)$ did not hold any mutual funds. This signifies that there is still ample room for growth in the mutual fund industry in Malaysia.

Table 2 presents the descriptive statistics for risk tolerance and the investment literacy score for the tested respondents. In terms of risk tolerance level, close to $37 \%$ of respondents indicated that they are willing to take average financial risk expecting to earn average returns. The mean of risk tolerance is 2.28 (over a maximum score of 4 ) indicating that respondents were willing to take some financial risk slightly above the moderate risk tolerance level (2.0), if they are compensated with a reward. Meanwhile, the investment literacy mean was 0.50 indicating that the respondents scored $50 \%$ out of $100 \%$ and they answered half of the investment literacy questions correctly. The evidence suggests a moderate level of investment literacy among the respondents.

Table 2 shows the descriptive statistics for risk tolerance and investment literacy. 
Table 2: Descriptive Statistics for Risk Tolerance and Investment Literacy

\begin{tabular}{llcccccccc}
\hline & N & Min & Max & Mean & SD & \multicolumn{2}{c}{ Skewness } & \multicolumn{2}{c}{ Kurtosis } \\
& & & & & & Statistic & Std. & Statistic & Std. \\
& & & & & & & Error & & Error \\
\hline RiskTol & 260 & 1.00 & 4.00 & 2.2846 & 1.03031 & 0.346 & 0.151 & -1.008 & 0.301 \\
Inv.Literacy & 260 & 0.00 & 0.94 & 0.5084 & 0.24587 & 0.107 & 0.151 & -1.096 & 0.301 \\
\hline \hline
\end{tabular}

\subsection{Association Between Sociodemographic Variables and Investment Literacy}

The first objective of this study is to examine the profile of individuals with low investment literacy vis-à-vis high investment literacy (i.e. to determine the association between sociodemographic variables and investment literacy). One-way ANOVA tests were conducted to achieve this objective, since investment literacy is measured as a continuous variable indicative of the score obtained for the investment literacy questions, while the demographic variables are categorical in nature. Overall, results of the one-way ANOVA tests indicate significant associations between investment literacy and demographic variables, which allow the researchers to understand the profile of individuals with low investment literacy vis-à-vis high investment literacy.

Prior to conducting the ANOVA tests, the Levene's test of homogeneity of variances was first conducted to check whether the variances in scores are the same for each of the subgroups within each demographic variable. For variables that had violated the assumption of homogeneity of variance, the Brown-Forsythe Robust Tests of Equality of Means was employed. All variables passed the assumption of variance homogeneity.

Table 3 displays the results of the one-way ANOVA tests, which reveal statistically significant differences in the score across age groups $(F=11.547,3 ; p<0.01)$, religious groups $(F=11.71,4$; $p<0.01)$, occupation levels $(F=16.186,4 ; p<0.01)$, income $(F=16.775,4 ; p<0.01)$ and education background $(F=14.816,4 ; p<0.01)$. Results of an independent sample t-test (Table 4) show that there are statistically significant differences in the mean score of investment literacy across genders $(t=3.721, p<0.01)$.

Table 3: Investment Literacy Across Demographic Groups

\begin{tabular}{|c|c|c|c|c|c|c|c|c|c|c|}
\hline & \multicolumn{4}{|c|}{ Mean difference across subgroups } & \multicolumn{6}{|c|}{ One-way ANOVA Test } \\
\hline & & $\mathbf{N}$ & Mean & SD & & $\begin{array}{l}\text { Sum of } \\
\text { Squares }\end{array}$ & df & $\begin{array}{c}\text { Mean } \\
\text { Square }\end{array}$ & $\mathbf{F}$ & $\rho$ \\
\hline \multirow[t]{4}{*}{ Gender } & Male & 120 & 0.568 & 0.024 & & & & & & \\
\hline & Female & 140 & 0.457 & 0.019 & & & N/A & & & \\
\hline & $20-25$ & 95 & 0.403 & 0.207 & & & & & & \\
\hline & $26-35$ & 118 & 0.548 & 0.244 & & & & & & \\
\hline \multirow[t]{2}{*}{ Age } & $36-45$ & 37 & 0.628 & 0.232 & $\begin{array}{c}\text { Between } \\
\text { Groups }\end{array}$ & 1.866 & 3 & 0.622 & 11.547 & 0.000 \\
\hline & 46 and above & 10 & 0.6 & 0.309 & $\begin{array}{l}\text { Within } \\
\text { Groups }\end{array}$ & 13.791 & 256 & 0.054 & & \\
\hline Religion & Islam & 114 & 0.412 & 0.216 & & & & & & \\
\hline
\end{tabular}




\begin{tabular}{|c|c|c|c|c|c|c|c|c|c|c|}
\hline & \multicolumn{4}{|c|}{ Mean difference across subgroups } & \multicolumn{6}{|c|}{ One-way ANOVA Test } \\
\hline & Buddhist & 83 & 0.621 & 0.235 & \multirow{4}{*}{$\begin{array}{c}\text { Between } \\
\text { Groups } \\
\text { Within } \\
\text { Groups }\end{array}$} & & & & \multirow{4}{*}{11.071} & \multirow{4}{*}{0.000} \\
\hline & Christian & 35 & 0.573 & 0.242 & & & & & & \\
\hline & Hindu & 19 & 0.457 & 0.233 & & 2.317 & 4 & 0.579 & & \\
\hline & Others & 9 & 0.542 & 0.272 & & 13.341 & 255 & 0.052 & & \\
\hline \multirow{5}{*}{ Occupation } & Clerical/Jr Exec & 121 & 0.395 & 0.206 & \multirow{5}{*}{$\begin{array}{l}\text { Between } \\
\text { Groups } \\
\text { Within } \\
\text { Groups }\end{array}$} & & & & \multirow{5}{*}{16.186} & \multirow{5}{*}{0.000} \\
\hline & Executive & 73 & 0.597 & 0.22 & & & & & & \\
\hline & Management & 43 & 0.654 & 0.228 & & & & & & \\
\hline & Senior Mgmt & 14 & 0.603 & 0.323 & & 3.17 & 4 & 0.793 & & \\
\hline & Others & 9 & 0.472 & 0.214 & & 12.487 & 255 & 0.049 & & \\
\hline \multirow{6}{*}{ Income } & Less than & 122 & 0.396 & 0.211 & \multirow{6}{*}{$\begin{array}{c}\text { Between } \\
\text { Groups } \\
\text { Within } \\
\text { Groups } \\
\end{array}$} & & & & \multirow{6}{*}{16.775} & \multirow{6}{*}{0.000} \\
\hline & RM2,500 & & & & & & & & & \\
\hline & $\begin{array}{l}\text { RM2,501 - } \\
\text { RM5,000 }\end{array}$ & 69 & 0.569 & 0.244 & & & & & & \\
\hline & $\begin{array}{l}\text { RM5,001 - } \\
\text { RM7,500 }\end{array}$ & 38 & 0.612 & 0.205 & & & & & & \\
\hline & $\begin{array}{l}\text { RM7,501 - } \\
\text { RM10,000 }\end{array}$ & 15 & 0.708 & 0.151 & & 3.262 & 4 & 0.815 & & \\
\hline & $\begin{array}{l}\text { RM10,001 \& } \\
\text { above }\end{array}$ & 16 & 0.676 & 0.270 & & 12.396 & 255 & 0.049 & & \\
\hline \multirow{5}{*}{$\begin{array}{l}\text { Education } \\
\text { Background }\end{array}$} & Arts & 29 & 0.304 & 0.159 & \multirow{5}{*}{$\begin{array}{c}\text { Between } \\
\text { Groups } \\
\text { Within } \\
\text { Groups }\end{array}$} & & & & \multirow{5}{*}{2.174} & \multirow{5}{*}{0.116} \\
\hline & $\begin{array}{l}\text { Business / } \\
\text { Econs }\end{array}$ & 124 & 0.598 & 0.223 & & & & & & \\
\hline & Engineering & 20 & 0.594 & 0.24 & & & & & & \\
\hline & Science & 33 & 0.464 & 0.238 & & 0.261 & 2 & 0.13 & & \\
\hline & Others & 54 & 0.409 & 0.236 & & 15.397 & 257 & 0.06 & & \\
\hline \multirow{4}{*}{ Education level } & High & & & & & & & & \multirow{4}{*}{14.816} & \multirow{4}{*}{0.000} \\
\hline & $\begin{array}{l}\text { school/Diploma/ } \\
\text { Others }\end{array}$ & 52 & 0.45 & 0.206 & & & & & & \\
\hline & Degree & 141 & 0.514 & 0.246 & $\begin{array}{l}\text { Between } \\
\text { Groups }\end{array}$ & 2.953 & 4 & 0.738 & & \\
\hline & Postgraduate & 67 & 0.542 & 0.268 & $\begin{array}{l}\text { Within } \\
\text { Groups }\end{array}$ & 12.705 & 255 & 0.05 & & \\
\hline
\end{tabular}

Table 4: Independent Sample T-Test (Investment Literacy Across Genders)

\begin{tabular}{llrrr}
\hline & & $\mathrm{t}$ & $\mathrm{df}$ & \multicolumn{1}{c}{ sig } \\
\hline \multirow{3}{*}{ Gender } & Equal variances assumed & 3.721 & 258 & 0.000 \\
& $\begin{array}{l}\text { Equal variances not } \\
\text { assumed }\end{array}$ & 3.675 & 235.244 & 0.000 \\
\hline \hline
\end{tabular}


Detailed results of the differences in investment literacy mean scores are presented in Table 3 . Males had a significantly higher investment literacy score $(\mu=0.57, \mathrm{SD}=0.024)$ compared to females $(\mu=0.46, \mathrm{SD}=0.019)$. Among age groups, those within the age range of $36-45$ had the highest investment literacy $(\mu=0.63, \mathrm{SD}=0.232)$ and the lowest age group had the lowest investment literacy $(\mu=0.40, \mathrm{SD}=0.207)$. Buddhist respondents displayed the highest investment literacy score $(\mu=0.62, \mathrm{SD}=0.235)$ and the Muslims had the lowest score $(\mu=0.41, \mathrm{SD}=0.216)$. Respondents who were working in the management level appeared to be more financially literate in investment matters $(\mu=0.65, \mathrm{SD}=0.220)$ and those who were in the clerical/junior executive level had the lowest investment literacy $(\mu=0.35, \mathrm{SD}=0.206)$. In regards to income, those in the income range of $\mathrm{RM} 7,501-10,000$ achieved the highest investment literacy scores $(\mu=0.71, \mathrm{SD}=0.151)$ while those in the lowest income group achieved the lowest investment literacy scores $(\mu=0.40$, $\mathrm{SD}=0.211$ ). In this study the highest income group (RM10,001 and above) had a slightly lower investment literacy score than the respondents from the RM7,501-RM10,000 group, however the difference is marginal. Respondents with Business/Economics and Engineering education background scored highest in the investment literacy measurement $\left(\mu_{\text {Business } / E \text { cons }}=0.59, \mathrm{SD}=0.223\right.$; $\left.\mu_{\text {Engineering }}=0.59, \mathrm{SD}=0.24\right)$ while respondents with Arts background scored the lowest $(\mu=0.30$, $\mathrm{SD}=0.159)$.

Overall, results of the one-way ANOVA tests and independent sample t-test provide evidence that there are significant differences in investment literacy across demographic factors (gender, age, religion, income level, education level and education background). The findings allow the researchers to infer that the profile of respondents who had high investment literacy scores were typically males, those with Business/Economic and Engineering education background, those in the high income range, working at the manager and executive levels, and those who profess Buddhism. On the other hand, the profile of the investment illiterate (i.e. scoring below average in investment literacy) individuals were females, those with Arts and Science education backgrounds, those in the low income groups and who worked as Junior executives (employed less than 5 years), as well as Muslim individuals. Similar to Lusardi and Mitchell (2007b), this study found that generally, male working adults in Malaysia tend to have higher investment literacy scores than females. In terms of income level, the findings confirm that respondents with a higher level of income tend to have higher investment literacy which supports the evidence reported by Fonseca et al. (2012) and Hassan Al-Tamimi and Anood Bin Kalli (2009). Similar to Lusardi and Mitchell (2011a), the researchers found that Muslim respondents tend to have lower investment literacy compared to other religions. In addition, Buddhist respondents have the highest investment literacy. As suggested by the literature, they are found to be more knowledgeable regarding loan products (Bakar, Masud \& Jusoh, 2006) and are good mathematically (Ismail \& Awang, 2008).

\subsection{Mutual Fund Investments}

To test the second research objective, which is to explore the impact of investment literacy and risk tolerance on the likelihood of investing in mutual funds, a logistic regression analysis was run due to the dichotomous nature of the dependent variable, i.e. whether or not the respondent held any mutual fund investments in their financial portfolios. In this model, other factors are controlled, namely the demographic variables such as gender, age, religion, income level, education background and education level.

The logistic regression is specified as follows: 


$$
\operatorname{Logit}(Y)=\ln \frac{\pi}{1-\pi}=\alpha+\beta_{1} X_{1}+B_{2} X_{2}+\beta_{3} X_{3}+\varepsilon
$$

(equation 1)

where, $\pi$ is the probability of investing in mutual funds (dummy variable), $\alpha$ is the $Y$ intercept, $X_{I}$ is investment literacy (continuous variable), $X_{2}$ is risk tolerance levels (dichotomous variables), $X_{3}$ is a vector of control variables representing demographic factors, $\beta$ are the coefficients to be estimated and $\varepsilon$ is the error term. A logistic regression predicts the log odds of an event outcome from a set of predictors (Peng, Lee $\&$ Ingersoll, 2002). In a logit model, $\alpha$ and $\beta$ are estimated by the maximum likelihood (ML) method, which is more appropriate given the data parameters of the dichotomous outcome of 0 or 1 . For easy interpretation, this study reports the odds ratio rather than the coefficients. Data was analysed using STATA v.10 SE. Results of the logistic regression are presented in Table 5.

Table 5: Logistic Regression on Holding Mutual Fund Investments

\begin{tabular}{llccc}
\hline \hline & & Odds ratio & Std. Err. & $\mathbf{z}$ \\
\hline Investment Literacy & Investment Literacy & 34.273 & 33.656 & $3.60^{* * *}$ \\
\hline Risk tolerance & Take average fin. risk & 1.329 & 0.714 & 0.53 \\
(base group is Not & Take above average fin. risk & 1.242 & 0.772 & 0.35 \\
willing to take any & Take substantial fin. risk & 1.373 & 0.855 & 0.51 \\
financial risk) & & & & \\
\hline Gender & Male & 1.645 & 0.644 & 1.27 \\
(base group is & & & & \\
Female) & & & & \\
& & & & \\
\hline Religion & Buddha & 1.085 & 0.482 & 0.18 \\
(base group is Islam) & Christian & 0.289 & 0.185 & $-1.94^{*}$ \\
& Hindu & 0.155 & 0.141 & $-2.04^{* *}$ \\
& Other & 0.722 & 0.868 & -0.27 \\
\hline Income level & RM2,501 - RM5,000 & 2.133 & 1.504 & 1.07 \\
(base group is & RM5,001 - RM7,500 & 2.744 & 2.231 & 1.24 \\
RM2,500 and below) & RM7,501 - RM10,000 & 2.658 & 2.756 & 0.94 \\
& RM10,001 \& above & 15.016 & 16.261 & $2.50^{* *}$ \\
\hline Education background & Arts & 0.051 & 0.070 & $-2.17^{* *}$ \\
(base group is & Engineering & 1.511 & 0.911 & 0.68 \\
Business/Economics) & Science & 0.616 & 0.369 & -0.81 \\
& Other Major & 0.375 & 0.204 & $-1.80^{*}$ \\
\hline Age group & 26-35 & 2.295 & 1.373 & 1.39 \\
(base group is 20-25) & 36-45 & 1.843 & 1.529 & 0.74 \\
& 46 and above & 1.484 & 1.800 & 0.33 \\
\hline Occupation & Executive & 0.977 & 0.711 & -0.03 \\
(base group is & Management & 1.054 & 0.847 & 0.07 \\
Clerical/Junior Exec.) & Senior Mgmt & 12.512 & 13.526 & $2.34^{* *}$ \\
& Other Occupation & 9.006 & 10.121 & $1.96^{* *}$ \\
\hline Education level & High school / college /diploma/others & 0.945 & 0.500 & -0.11 \\
(base group is Degree) & Postgraduate & 0.897 & 0.428 & -0.23 \\
\hline \hline
\end{tabular}

Notes: $\quad$ (1) $n=260$, LR Chi-square (26) $=133.36$, Prob $>$ chi $^{2}=0.000$, Pseudo $\mathrm{R}^{2}=0.3947$

(2) *, ** and $* * *$ denotes $10 \%, 5 \%$ and $1 \%$ significance level, respectively 
The footnote in Table 5 indicates that the total sample is 260 , and the likelihood ratio chi-square $\left(\mathrm{LR} \mathrm{chi}^{2}\right)$ is $128.77(\mathrm{df}=26, p<0.01)$. This suggests that the null hypothesis that all coefficients of the predictors in the model are equal to zero can be rejected. Since the probability of the LR test statistic is significant at $p<0.01$, it can be inferred that the predictors in the model do indeed have an effect on the outcome variable. Results of the logistic regression also produces the McFadden's Pseudo $R^{2}$ of 0.3947 . The value of the Pseudo $\mathrm{R}^{2}$ is unlike the $\mathrm{R}^{2}$ reported in ordinary least square regression. Pseudo $\mathrm{R}^{2}$ with small ratios of $\log$ likelihoods suggest that the overall full model is acceptable, fitting significantly better than a model with no predictors. Hence, the Pseudo $R^{2}$ of this model is deemed acceptable.

The results of the logistic regression reveal that the relationship between investment literacy and the odds of having mutual fund investment is positive and significant $(O R=34.72, p<0.01)$, suggesting that an individual with higher investment literacy would have significantly higher odds of holding mutual fund investments. This result lends support to the first hypothesis, $\boldsymbol{H}_{\boldsymbol{1}}$. In the same perspective with previous literature (e.g. Sivaramakrishnan et al., 2017; Müller \& Weber, 2010; Jonsson et al., 2017), more financially literate investors were more likely to invest in mutual funds compared to those who were less financially literate.

Interestingly, the results show that risk tolerance does not significantly influence the likelihood of investing in mutual funds. As can be noted from Table 5, there were no differences in the probability of holding mutual funds between the different levels of risk tolerance. Therefore, there is no evidence to support $\boldsymbol{H}_{2}$ since risk tolerance does not influence the likelihood of investing in mutual funds in the context of this study. The literature suggests that risk tolerance plays a significant role in determining the individual investment decision (Jagongo \& Mutswenje, 2014; Mahmood et al., 2011). However, contradicting a priori, risk tolerance did not affect the likelihood of individuals investing in mutual funds. The insignificant result may be due to the risk diversification feature of mutual funds compared to direct stock market investments. There are many types of funds offered by mutual companies that match the risk profile of investors (e.g. equity funds, fixed income funds, balanced funds, and others), hence, investors are able to choose funds that match their risk appetites. Furthermore, investors do not have to be actively involved in rebalancing their investment portfolios in response to financial assets price fluctuations since they can rely on the expertise of the professional fund managers in the reallocation of investments in their portfolio while maintaining the investors' targeted risk-reward objectives.

In terms of religion, Hindus $(O R=-1.55, p<0.05)$ and Christians $(O R=0.29, p<0.10)$ were significantly less likely as opposed to the reference group (the Muslims) in holding mutual fund investments. This evidence is possibly due to the fact that there are now more attractive and innovative Shari'ah-complaint mutual fund products being offered in the market that Muslims in particular, may find attractive. Being Shari'ah-compliant is the most important criteria in selecting mutual fund products for Muslims (Jamaludin, Smith \& Gerrans, 2012), hence having a huge variety of Shari'ah compliant mutual fund products available in the market may further boost the Muslim penetration to invest in these Shari'ah-compliant mutual fund products compared to individuals of other religions.

Those in the highest income group were significantly more likely to have mutual fund investments compared to the reference group (lowest level income). This is because respondents that fall under the highest income group tend to have more income buffer to be allocated for mutual investment 
funds compared to respondents in the lower income group. The lower income group is more cautious in their investments and they allocate their limited income for other saving alternatives rather than higher risk investment options (Geetha \& Ramesh, 2011). In regards to education background, individuals from the Arts background $(O R=0.051, p<0.01)$ and Other majors $(O R=0.375, p<0.05)$ were found to have a lower likelihood of holding mutual fund investments as opposed to the base group (Business/Economics). Individuals working in Senior management $(O R=12.51, p<0.01)$ positions and other occupation levels were also more likely to have mutual fund investments relative to the base group (Junior executives) $(O R=9.01, p<0.01)$.

In a nutshell, these results infer that those who are more likely to invest in mutual funds are Muslim and Buddhist investors, those who are more literate in investment matters, higher income earners, hold higher senior positions and those who come from Business and Economics education background. Contrary to Jamaludin and Gerrans's (2015) findings, this study found significant results between both proxies (education background and religious beliefs) and the participation in mutual funds among Malaysian working adults. In addition, this study shows that Christians and Hindus were less likely to have mutual fund investments as opposed to Muslims and those from the Arts background and other majors were also less likely compared to those with Business and Economics backgrounds.

\section{CONCLUSION}

Based on the research findings, two main practical implications are generated. First, the researchers found that individual with higher investment literacy would have significantly higher odds of holding mutual fund investments $\left(H_{l}\right)$. Therefore, to increase more mutual fund penetration among Malaysian working adults, the regulator (Bank Negara Malaysia and Securities Commission) need to focus more on activities to enhance the level of investment literacy among the working adults. Since the statistics showed that those with low levels of investment literacy were females, those with Arts and Science education backgrounds, those in the low income groups and who worked as Junior executives (employed less than 5 years), as well as Muslim individuals, the regulators may consider conducting various financial education workshops segmented to these targeted audiences. The Securities Commission could conduct these workshops for university/college students who major in those fields in order to disseminate the importance of financial planning via mutual fund participation. The workshops may explain the basic concepts in investment planning that may be easily comprehended by these non-business/economic background customers. By increasing the understanding of financial planning concepts, these groups of people may have better confidence to evaluate the most appropriate mutual funds that are suited to their risk-reward attitudes.

In addition, this study also found significant differences in the likelihood of participating in mutual funds among individuals across different education and religious beliefs. The findings highlight that Christians and Hindus were less likely to have mutual fund investments as opposed to Muslims and those from the Arts background and other majors were also less likely compared to those with Business and Economics background. Although Christians and Hindus have higher investment literacy scores compared to Muslims, the results show that they are less likely to participate in mutual funds. These results are rather interesting, as it implies that the Muslims (presumably majority being Malays) are investing in mutual funds even though they are less literate in 
investment matters. These findings derive to the second practical implication where to enhance the informed potential mutual fund investors, the mutual fund providers may consider embarking an aggressive knowledge sharing videos related to mutual funds via comprehensive nonmainstream advertisement channels such as radio and digital marketing. According to the Malaysian Digital Association (2016), on average, each individual in Malaysia spends more than half of their Internet time engaging in social media such as Facebook, YouTube, Instagram and Twitter, and the usage is the highest under the social media platform. Hence, advertisements promoting mutual investments via social media such as online Christian radio channels or Youtube that are targeted to Christians and Hindus may be more targeted and effective. Through these comprehensive advertisements and seminars, financial service providers may be able to increase the awareness regarding mutual fund products among these two groups and further attract them to participate in mutual funds. Furthermore, there is a wide range of funds comprising of conventional to Shari'ah-compliant funds available in the Malaysian marketplace for Christian and Hindu investors to choose according to their preferences and risk tolerance levels.

This study has two limitations. First is related to the sampling technique, which results in a sample of relatively well-educated working adults in Kuala Lumpur. The convenience sampling approach may render the results to be ungeneralisable to the overall working population in Malaysia. Future research could extend the sampling selection to cater for working adults in all cities across Malaysia. Second, in relation to the mutual fund investment measurement, this study used a simple binary variable to gauge whether the respondents held mutual fund investments or otherwise. There are advantages as well as disadvantages of using such measurement. The advantage is that the question can be easily understood and is simple for the respondents to answer without having to report the exact monetary amounts invested in mutual funds. However, the simplicity of this measurement may be viewed as a limitation, and future studies could perhaps use a more quantitative measurement of mutual fund investments.

\section{ACKNOWLEDGEMENT}

The researchers would like to acknowledge the financial support provided by the University of Malaya Faculty Research Grant (Geran Penyelidikan Fakulti) No. GPF009I-2019 (Faculty of Business and Accountancy).

\section{REFERENCES}

Alexander, G. J., Jones, J. D., \& Nigro, P. J. (1998). Mutual fund shareholders: characteristics, investor knowledge, and sources of information. Financial Services Review, 7(4), 301316.

Ali, A., Rahman, M. S. A., \& Bakar, A. (2015). Financial satisfaction and the influence of financial literacy in Malaysia. Social Indicators Research, 120(1), 137-156.

Almenberg, J., \& Dreber, A. (2015). Gender, stock market participation and financial literacy. Economics Letters, 137, 140-142.

Arathy, B., Nair, A. A., Sai, A., \& Pravitha, N. R. (2015). A study on factors affecting investment on mutual funds and its preference of retail investors. International Journal of Scientific and Research Publications, 5(8), 430-433. 
Athey, L. A., \& Kennickell, A. B. (2005). Managing Data Quality on the 2004 Survey of Consumer Finances. Annual Meetings of the American Association for Public Opinion Research, Miami Beach, Florida, May 12-15.

Atkinson, A., \& F. Messy (2012). Measuring Financial Literacy: Results of the OECD / International Network on Financial Education (INFE) Pilot Study, OECD Working Papers on Finance, Insurance and Private Pensions, No. 15, OECD Publishing, Paris. Retrieved from http://dx.doi.org/10.1787/5k9csfs90fr4-en

Bakar, E. A., Masud, J., \& Jusoh, Z. M. (2006). Knowledge, attitude and perceptions of university students towards educational loans in Malaysia. Journal of Family and Economic Issues, 27(4), 692-701.

Barro, R., \& McCleary, R. (2003). Religion and economic Growth. American Sociological Review, 68(5), 760-781.

Bello, D., Leung, K., Radebaugh, L., Tung, R. L., \& Van Witteloostuijn, A. (2009). From the editors: Student samples in international business research. Journal of International Business Studies, 40(3), 361-364.

Benjamin, D. J., Choi, J. J., \& Fisher, G. (2016). Religious identity and economic behavior. Review of Economics and Statistics, 98(4), 617-637.

Boon, T. H., Yee, H. S., \& Ting, H. W. (2011). Financial literacy and personal financial planning in Klang Valley, Malaysia. International Journal of Economics and Management, 5(1), $149-168$.

Brimble, M., Vyvyan, V., \& Ng, C. (2013). Belief and investing: Preferences and attitudes of the faithful. Australasian Accounting, Business and Finance Journal, 7(1), 23-41.

Chatman, J. A., \& Barsade, S. G. (1995). Personality, organizational culture, and cooperation: Evidence from a business simulation. Administrative Science Quarterly, 423-443.

Chu, Z., Wang, Z., Xiao, J. J., \& Zhang, W. (2017). Financial Literacy, Portfolio Choice and Financial Well-Being. Social Indicators Research, 132(2), 799-820.

Cocco, J. F., Gomes, F. J., \& Maenhout, P. J. (2005). Consumption and portfolio choice over the life cycle. Review of Financial Studies, 18(2), 491-533.

Cohn, R. A., Lewellen, W. G., Lease, R. C., \& Schlarbaum, G. G. (1975). Individual investor risk aversion and investment portfolio composition. The Journal of Finance, 30(2), 605-620.

Constantinides, G. M., Donaldson, J. B., \& Mehra, R. (2002), Junior can't borrow: A new perspective on the equity premium puzzle. Quarterly Journal of Economics, 117(1), 269296.

Davar, Y. P., \& Gill, S. (2007). Investment decision making: An empirical study of perceptual view of Investors. Metamorphosis, 6(2), 115-135.

Deb, S., \& Singh, R. (2016). Impact of risk perception on investors towards their investment in mutual fund. Pacific Business Review International, 1(2), 16-23.

Department of Statistics Malaysia (n.d.). Federal Territory of Kuala Lumpur@a Glance. Retrieved from https:/www.dosm.gov.my/v1/index.php?r=column/cone\&menu_id= bjRlZXVGdnBueDJKY1BPWEFPRlhIdz09

Eeckhoudt, L., Gollier, C., \& Schlesinger, H. (2005). Economic and Financial Decisions Under Risk. Princeton: Princeton University Press.

Fauzi, A. A., Husniyah, A. R., Fazli, S. M., \& Amim, O. M. (2017). Financial risk tolerance as a predictor for malaysian employees' gold investment behavior. In M.H. Bilgin et al. (Eds.), Regional Studies on Economic Growth, Financial Economics and Management, Eurasian Studies in Business and Economics 7. Retrieved from DOI 10.1007/978-3-31954112-9 5 
Ferguson, A. J., \& Peterson, R. S. (2015). Sinking slowly: Diversity in propensity to trust predicts downward trust spirals in small groups. Journal of Applied Psychology, 100(4), 1012.

Fonseca, R., Mullen, K. J., Zamarro, G., \& Zissimopoulos, J. (2012). What explains the gender gap in financial literacy? The role of household decision making. Journal of Consumer Affairs, 46(1), 90-106.

Fornero, E., \& Monticone, C. (2011). Financial literacy and pension plan participation in Italy. Journal of Pension Economics \& Finance, 10(4), 547-564.

Friedman, R., Chi, S. C., \& Liu, L. A. (2006). An expectancy model of Chinese-American differences in conflict-avoiding. Journal of International Business Studies, 37(1), 76-91.

Geetha, N., \& Ramesh, M. (2011). A study on people's preferences in investment behaviour. International Journal of Engineering and Management Research, 1(6), 285-306.

Gerardi, K., Goette, L., \& Meier, S. (2010). Financial literacy and subprime mortgage delinquency: Evidence from a survey matched to administrative data. Working Paper. April 2010.

Giannetti, M., \& Koskinen, Y. (2010). Investor protection, equity returns, and financial globalization. Journal of Financial and Quantitative Analysis, 45(1), 135-168.

Gilliam, J., Chatterjee, S., \& Grable, J. E. (2010). Measuring the perception of financial risk tolerance: A tale of two measures. Journal of Financial Counselling and Planning, 21(2).

Gittleman, M., \& Wolff, E. N. (2004). Racial differences in patterns of wealth accumulation. Journal of Human Resources, 39(1), 193-227.

Goldsmith, E. B. (2009). Consumer economics: Issues and behaviors. Upper Saddle River, NJ: Pearson/ Prentice Hall.

Grable, J., \& Lytton, R. H. (1999). Financial Risk tolerance revisited: The development of a risk assessment instrument. Financial Services Review, 8(3), 163-181.

Guiso, L., \& Viviano, E. (2014). How much can financial literacy Help? Review of Finance, 19(4), 1347-1382.

Hassan Al-Tamimi, H. A., \& Anood Bin Kalli, A. (2009). Financial literacy and investment decisions of UAE investors. The Journal of Risk Finance, 10(5), 500-516.

Hastings, J., \& Mitchell, O. S. (2011). How financial literacy and impatience shape retirement wealth and investment behaviors. Journal of Pension Economics \& Finance, 19(1), 1-20.

Heo, W., Grable, J. E., \& O’Neill, B. (2017). Wealth accumulation inequality: Does investment risk tolerance and equity ownership drive wealth Accumulation? Social Indicators Research, 133(1), 209-225.

Hess, D.W. (2012). The impact of religiosity on personal financial decisions. Journal of Religion and Society, 14, 1-13.

Huston, S. J. (2010). Measuring financial literacy. Journal of Consumer Affairs, 44(2), 296-316.

Idris, F. H., Krishnan, K. S. D., \& Azmi, N. (2013). Relationship between financial literacy and financial distress among youths in Malaysia-An empirical study. Geografia-Malaysian Journal of Society and Space, 9(4), 106-117.

Ismail, N. A., \& Awang, H. (2008). Differentials in Mathematics achievement among eighth-grade students in Malaysia. International Journal of Science and Mathematics Education, 6(3), 559-571.

Jacobs-Lawson, J. M., \& Hershey, D. A. (2005). Influence of future time perspective, financial knowledge, and financial risk tolerance on retirement saving behaviors. Financial Services Review, 14(4), 331-344.

Jagongo, A. O., \& Mutswenje, V. S. (2014). A survey of the factors influencing investment decisions: The Case of individual investors at the NSE. International Journal of Humanities and Social Science, 4(4), 92-102. 
Jaiyeoba, H. B., Adewale, A. A., Haron, R., \& Che Ismail, C. M. H. (2018). Investment decision behaviour of the Malaysian retail investors and fund managers: A qualitative inquiry. Qualitative Research in Financial Markets, 10(2), 134-151.

Jamaludin, N., \& Gerrans, P. (2015). Retirement savings investment decisions: Evidence from Malaysia. Journal of the Asia Pacific Economy, 20(4), 644-657.

Jamaludin, N., Smith, M., \& Gerrans, P. (2012). Mutual fund selection criteria: Evidence from Malaysia. Asian Review of Accounting, 20(2), 140-151.

Jonsson, S., Söderberg, I. L., \& Wilhelmsson, M. (2017). An investigation of the impact of financial literacy, risk attitude, and saving motives on the attenuation of mutual fund investors' disposition bias. Managerial Finance, 43(3), 282-298.

Kaur, I., \& Kaushik, K. P. (2016). mutual fund ownership and sponsor background: Effect on performance and risk strategy. International Journal of Management Practice, 9(3), 282301.

Khorana, A., Servaes, H., \& Tufano, P. (2005). Explaining the size of the mutual fund industry around the world. Journal of Financial Economics, 78(1), 145-185.

León, A. K., \& Pfeifer, C. (2013). Religious Activity, Risk Taking Preferences, and Financial Behaviour: Empirical Evidence from German Survey Data. Federal Reserve Bank of St Louis, St. Louis. Retrieved from http://ezproxy.um.edu.my/docview/1698742508? accountid $=28930$

Lusardi, A., \& Mitchell, O. S. (2005). Financial Literacy and Planning: Implications for Retirement Wellbeing. Michigan Retirement Research Centre Research Paper, No. w17078.

Lusardi, A., \& Mitchell, O. S. (2007a). Baby boomer retirement Security: The roles of planning, financial literacy, and housing wealth. Journal of Monetary Economics, 54(1), 205-224.

Lusardi, A., \& Mitchell, O.S. (2007b). Financial literacy and retirement preparedness: Evidence and implications for financial education. Business Economics, 42(1), 35-44.

Lusardi, A., \& Mitchell, O.S. (2008). Planning and financial literacy: How do women fare? National Bureau of Economic Research, No. w13750.

Lusardi, A., \& Mitchell, O.S. (2011a). Financial literacy around the world: An overview. Journal of Pension Economics and Finance, 10(4), 497-508.

Lusardi, A., \& Mitchell, O.S. (2011b). Financial literacy and planning: Implications for retirement wellbeing. National Bureau of Economic Research, No. w17078.

Lusardi, A., \& Scheresberg, C. D. B. (2013). Financial literacy and high-cost borrowing in the United States. National Bureau of Economic Research, No. w18969.

Mahdzan, N.S. \& Tabiani, S. (2013) The impact of financial literacy on individual saving: An exploratory study in the Malaysian context. Transformations in Business \& Economics, 12(1), 41-55.

Mahmood, I., Ahmad, H., Khan, A. Z., \& Anjum, M. (2011). behavioral implications of investors for investments in the stock market. European Journal of Social Science, 20(2), 240-247.

Malaysian Digital Association (2016). Malaysia Digital Landscape. Digital Integration \& Business Transformation Asia Conference, 3-4 August 2016, JW MARRIOTT Kuala Lumpur, Malaysia. Retrieved from http://www.malaysiandigitalassociation.org.my/wp-content/ uploads/2016/08/Malaysia-Digital-Landscape-August-2016.pdf

Markowitz, H. (1952). Portfolio selection. The Journal of Finance, 7(1), 77-91.

Müller, S., \& Weber, M. (2010). Financial literacy and mutual fund investments: Who buys actively managed funds? Schmalenbach Business Review, 62(2), 126-153. 
Norvilitis, J. M., Merwin, M. M., Osberg, T. M., Roehling, P. V., Young, P., \& Kamas, M. M. (2006). Personality factors, money attitudes, financial knowledge, and credit-card debt in college students. Journal of Applied Social Psychology, 36(6), 1395-1413.

Pellinen, A., Törmäkangas, K., Uusitalo, O., \& Raijas, A. (2011). Measuring the financial capability of investors: A case of the customers of mutual funds in Finland. International Journal of Bank Marketing, 29(2), 107-133.

Peng, C. Y. J., Lee, K. L., \& Ingersoll, G. M. (2002). An introduction to logistic regression analysis and reporting. The Journal of Educational Research, 96(1), 3-14.

Remund, D. L. (2010). Financial literacy explicated: The case for a clearer definition in an increasingly complex economy. Journal of Consumer Affairs, 44(2), 276-295.

Riley Jr, W. B., \& Chow, K. V. (1992). Asset allocation and individual risk aversion. Financial Analysts Journal, 48(6), 32-37.

Ripain, N., \& Ahmad, N. W. (2018). An overview of unit trust funds in Malaysia. Reports on Economics and Finance, 4(3), 117-123.

Rootman, C., \& Kruger, J. (2016). Determining consumers' intention to use unit trusts. Journal of Economic and Financial Sciences, 9(2), 436-454.

Sabri, M. F., MacDonald, M., Hira, T. K., \& Masud, J. (2010). Childhood consumer experience and the financial literacy of college students in Malaysia. Family and Consumer Sciences Research Journal, 38(4), 455-467.

Securities Commission. (2011). Capital Market Masterplan 2. Retrieved from https://www.sc.com.my/api/documentms/download.ashx?id=68e637ca-543b-47cc$9 \mathrm{~b} 4 \mathrm{~d}-0 \mathrm{a} 4 \mathrm{a} 282 \mathrm{fd} 5 \mathrm{c} 5$

Securities Commission. (2017). Annual Report 2017. Retrieved from https://www.sc.com.my/api/documentms/download.ashx?id=097e62ec-8464-46a2a3e0-9cb4ee164ca7

Sivaramakrishnan, S., Srivastava, M., \& Rastogi, A. (2017). Attitudinal factors, financial literacy, and stock market participation. International Journal of Bank Marketing, 35(5), 818-841.

The Star (2013, October 12). Unit trust's CG challenge. The Star Online. Retrieved from http://www.thestar.com.my/business/business-news/2013/10/12/the-industry-lackscorporate-governance-shareholder-activism/

The Star (2017, May 3). More young investors entering into Malaysian market. The Star Online. Retrieved from https://www.thestar.com.my/business/business-news/2017/05/03/younginvestors/\#sMyVXDfIeY3r2ZAL.99.

Thomas, A., \& Spataro, L. (2015). Financial literacy, human capital and stock market participation in Europe: An empirical exercise under endogenous framework. Discussion Papers del Dipartimento di Scienze Economiche-Università di Pisa, 2015-194.

Van Rooij, M., Lusardi, A., \& Alessie, R. (2011). Financial literacy and stock market participation. Journal of Financial Economics, 101(2), 449-472.

Wang, A. (2011). Younger generations' investing behaviors in mutual funds: Does gender matter? The Journal of Wealth Management, 13(4), 13-23.

Xia, T., Wang, Z., \& Li, K. (2014). Financial literacy overconfidence and stock market participation. Social Indicators Research, 119(3), 1233-1245.

Yoo, P. S. (1994). Age Dependent Portfolio Selection. Working Paper Series (No. 1994-003A). The Federal Reserve Bank of St. Louis. 
Yusuff, N., \& Mansor, F. (2016). Proposed model for the factors influencing Muslim investors in choosing Islamic unit trust funds. Journal of Global Business and Social Entrepreneurship, 1(2), 113-120. 